\title{
Yield of maize crop irrigated with saline waters
}

\author{
Valdécio dos S. Rodrigues ${ }^{1}$, Francisco M. L. Bezerra ${ }^{2}$, Geocleber G. de Sousa ${ }^{3}$, Jamili N. Fiusa ${ }^{2}$, \\ Kelly N. Leite ${ }^{4} \&$ Thales V. de A. Viana ${ }^{2}$
}

${ }^{1}$ Universidade Federal do Paraná. Curitiba, PR, Brasil. E-mail: valdeciorodrigues@hotmail.com (Corresponding author) - ORCID: 0000-0001-5344-2150

${ }^{2}$ Universidade Federal do Ceará. Fortaleza, CE, Brasil. E-mail: mbezerra@ufc.br - ORCID: 0000-0002-9334-8297; miilinobre@hotmail.com - ORCID: 0000-0002-2458-5010; thales@ufc.br - ORCID: 0000-0003-0722-6371

${ }^{3}$ Universidade da Integração Internacional da Lusofonia Afro-Brasileira. Redenção, CE, Brasil. E-mail: sousagg@unilab.edu.br - ORCID: 0000-00021466-6458

${ }^{4}$ Universidade Federal do Acre. Cruzeiro do Sul, AC, Brasil. E-mail: knleite.ufac@gmail.com - ORCID: 0000-0003-1919-9745

\begin{abstract}
The growing competition for good-quality water is forcing the use of saline water for irrigation in several areas around the world. The objective of this study was to evaluate the influence of different electrical conductivities of irrigation water on the maize production aspects. The study was conducted in the field from August to December 2017 at the Experimental Farm of the Universidade da Integração Internacional da Lusofonia Afro-Brasileira (UNILAB), Redenção, CE, Brazil. A randomized complete block design with five irrigation water salinity $\left(1.0,2.0,3.0,4.0\right.$ and $\left.5.0 \mathrm{dS} \mathrm{m}^{-1}\right)$ and four repetitions was used. The evaluated variables were: unhusked and husked ear weights, husked ear length and diameter, cob weight, 1000-grain weight and yield. The increase of salt concentration in irrigation water reduced the unhusked and husked ear weights, cob weight, 1000-grain weight and yield. Ear length and diameter were not influenced by the increase in water salinity.
\end{abstract}

Key words: Zea mays L., salt stress, crop yield

\section{Produtividade da cultura do milho irrigado com águas salinas}

RESUMO: A crescente competição por água de boa qualidade está forçando o uso de águas salinas para irrigação em diversas áreas ao redor do mundo. O objetivo deste estudo foi avaliar a influência de diferentes condutividades elétricas na água de irrigação sobre os aspectos produtivos do milho. O estudo foi conduzido em campo, no período de agosto a dezembro de 2017, na Fazenda experimental da Universidade da Integração Internacional da Lusofonia Afro-Brasileira (UNILAB), Redenção, CE, Brasil. O delineamento utilizado foi o

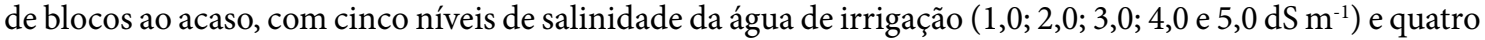
repetições. As variáveis avaliadas foram: massa da espiga com palha e sem palha, comprimento e diâmetro da espiga sem palha, massa do sabugo, massa de 1000 grãos e a produtividade. $O$ aumento da concentração dos sais na água de irrigação reduziu a massa da espiga com palha e sem palha, massa do sabugo, massa de 1000 grãos e a produtividade. O comprimento e o diâmetro da espiga não foram influenciados pelo aumento da salinidade da água.

Palavras-chave: Zea mays L., estresse salino, rendimento da cultura 


\section{INTRODUCTION}

The growth of the world's population is reaching a point at which good-quality water is becoming insufficient for the basic needs of mankind, including irrigation of farmland, as well as industrial and urban uses (Ashraf et al., 2017). In addition, the gap between water supply and demand is increasing due to unequal distribution of water resources and rapid socioeconomic development, particularly in arid and semiarid regions of the world (Ashraf et al., 2015).

Given the increasingly reduced supply of good-quality water resources, efforts have been made to enable the use of low quality waters in agriculture, that is, water with higher salt concentrations, which contributes to greater availability of good-quality water aiming for the domestic use, in addition to maximizing the efficiency of use of this resource (Holanda Filho et al., 2011).

Salinity is an abiotic stress which limits plant growth and yield worldwide. The excess of salts in many regions of arid and semiarid areas constitutes a serious obstacle for the production system, due to both the changes in soil physical and chemical attributes and the action of specific ions such as $\mathrm{Na}^{+}$and $\mathrm{Cl}$ (Santos et al., 2018).

Several studies with salinity in the maize crop were carried out in various regions, especially those of arid and semiarid climate (Nazário et al., 2013; Yu et al., 2014; Feng et al., 2017), and found reduction in plant development and yield, but there are few studies citing the influence of irrigation water salinity on plants of local varieties used by small producers.

In view of the above, this study was conducted to evaluate the yield of maize irrigated with saline water.

\section{Material ANd Methods}

The experiment was conducted in the field from August to October 2017 at the experimental farm of the Universidade da Integração Internacional da Lusofonia Afro-Brasileira (UNILAB), situated in the municipality of Redenção, CE, Brazil, located at the following geographic coordinates: $4^{\circ} 14^{\prime}$ $53^{\prime \prime} \mathrm{S}, 38^{\circ} 45^{\prime} 10^{\prime \prime} \mathrm{W}$ and altitude of $240 \mathrm{~m}$.

The climate of the region is BSh', which means very high temperature, with predominant rainfall in the summer and autumn seasons (Alvares et al., 2013). According to data, the region has an average annual rainfall of $1,086 \mathrm{~mm}$, average air temperature of $26^{\circ} \mathrm{C}$ and average air relative humidity of $71.3 \%$.

During the experiment, the average rainfall from August to December was $11 \mathrm{~mm}$, with air relative humidity of $70.41 \%$ and temperature of $27.3^{\circ} \mathrm{C}$.

For the soil chemical analyses, samples were collected at $0-20 \mathrm{~cm}$ depth, before applying the treatments in the experimental area (Table 1), following the methodology recommended by EMBRAPA (1997). For the texture, the soil is characterized as sandy loam, with density of $1.3 \mathrm{~kg} \mathrm{dm}^{-3}$.
The experimental design was randomized blocks with five irrigation water salinity $\left(1.0 ; 2.0 ; 3.0 ; 4.0\right.$ and $\left.5.0 \mathrm{dS} \mathrm{m}^{-1}\right)$ and four repetitions. Sowing was done manually with four seeds per hole, at spacing of $1.0 \times 0.3 \mathrm{~m}$ between the planting rows and between plants, respectively. Seeds of the Creole variety called 'Giant' were used.

At eight days after sowing (DAS), thinning was performed, leaving one plant per hole in a total of 20 plants in each 6-m plot, corresponding to the planting density of 33,333 plants $\mathrm{ha}^{-1}$. Irrigations with water of different salinity were initiated. The amount of water applied was calculated based on the crop coefficient $(\mathrm{Kc})$ and reference evapotranspiration $\left(\mathrm{ET}_{0}\right)$ (Doorenbos \& Kassam, 1994), estimated by the Class A Pan method, installed close to the experimental area, with a 2-day irrigation interval.

Saline waters were prepared using $\mathrm{NaCl}, \mathrm{CaCl}_{2} .2 \mathrm{H}_{2} \mathrm{O}$ and $\mathrm{MgCl}_{2} \cdot 6 \mathrm{H}_{2} \mathrm{O}$, in the proportion of $7: 2: 1$, in non-saline water $\left(0.5 \mathrm{dS} \mathrm{m}^{-1}\right)$, following the relationship between ECw and their concentrations $\left(\mathrm{mmol}_{\mathrm{c}} \mathrm{L}^{-1}=\mathrm{EC} \times 10\right)$, according to Rhoades et al. (2000). Irrigation was applied through drippers with flow rate of $8 \mathrm{~L} \mathrm{~h}^{-1}$, spaced by $0.30 \mathrm{~m}$, and the distribution uniformity coefficient (DUC) of approximately $90 \%$.

Irrigation time was estimated from Eq. 1;

$$
\mathrm{Ti}=\frac{\mathrm{ETc} \mathrm{Sp}}{\mathrm{Ea} \mathrm{q}} 60
$$

where:

$\mathrm{Ti}$ - irrigation time, min;

$\mathrm{ET}_{\mathrm{c}}$ - crop evapotranspiration, $\mathrm{mm}$;

Sp - spacing between drippers;

Ea - application efficiency, 0.9; and,

q - flow rate, $\mathrm{L} \mathrm{h}^{-1}$.

A leaching fraction of 0.15 (Ayers \& Westcot, 1999) was added to the water depth to be applied.

The experiment was harvested manually at 110 days after sowing, and a total of five ears per plot were collected. Subsequently, the ears (five in total) were dried for 15 days in a protected environment until reaching constant mass, when the following variables were determined: unhusked ear weight (UEW), husked ear weight (HEW), ear diameter (ED) and husked ear length (EL), cob weight (CW), 1000-grain weight (1000GW) and yield (Y).

The 1000-grain weight was determined by counting the grains and weighing on electronic scale with precision of $0.001 \mathrm{~g}$, with the results expressed in $\mathrm{g}$. Yield was estimated based on the total mass of the grains harvested in the plots and considering the area occupied by the plants.

The results were subjected to analysis of variance and regression, using the program Assistat 7.7 Beta (Silva \& Azevedo, 2016). In the regression analysis, the equations that

Table 1. Soil chemical characterization

\begin{tabular}{|c|c|c|c|c|c|c|c|c|c|c|c|c|c|}
\hline \multicolumn{14}{|c|}{ Chemical attributes } \\
\hline $\mathrm{OM}$ & $\mathbf{N}$ & $\mathbf{P}$ & $\mathrm{K}^{+}$ & $\mathrm{Ca}^{2+}$ & $\mathrm{Mg}^{2+}$ & $\mathrm{Na}^{+}$ & $\mathrm{H}^{+}+\mathrm{Al}^{3+}$ & $\mathbf{A l}$ & SB & CEC & \multirow{2}{*}{$\begin{array}{c}V \\
(\%)\end{array}$} & \multirow{2}{*}{$\mathrm{pH}$} & ECse \\
\hline & & $\left(\mathrm{mg} \mathrm{kg}^{-1}\right)$ & \multicolumn{8}{|c|}{$\left(\mathrm{cmol}_{\mathrm{G}} \mathrm{kg}^{-1}\right)$} & & & $\left(\mathrm{dS} \mathrm{m}^{-1}\right)$ \\
\hline 16.96 & 0.92 & 8 & 0.3 & 2.7 & 2.1 & 0.03 & 1.82 & 0.05 & 5.1 & 7 & 73 & 6.0 & 0.23 \\
\hline
\end{tabular}

OM - Organic matter; N - Nitrogen; SB - Sum of bases; CEC - Cation exchange capacity; V - Base saturation; ECse - Electrical conductivity of saturation extract 
best fitted the data were selected based on the significance of the regression coefficients at $p \leq 0.01$ and $p \leq 0.05$ by the $\mathrm{F}$ test and with the highest coefficient of determination $\left(\mathrm{R}^{2}\right)$.

\section{Results AND Discussion}

The analysis of variance (Table 2) showed that the unhusked and husked ear weights, cob weight, 1000-grain weight and yield were significantly influenced $(0.01 \geq p \leq 0.05)$ by the treatments, except for the variables diameter and length of husked ears.

According to the regression analysis (Figure 1A), a quadratic polynomial model fitted to the data of unhusked ear weight (UEW), which reached maximum value (77.05 $\mathrm{g}$ ) at water salinity of $2.34 \mathrm{dS} \mathrm{m}^{-1}$, being reduced by $36.86 \%$ when plants were irrigated with $5 \mathrm{dS} \mathrm{m}^{-1}$, compared to 1.0 $\mathrm{dS} \mathrm{m}^{-1}$. The reduction of this variable is the consequence of the accumulation of salts in the soil, which in turn negatively affects the good development of the plant throughout its cycle and, consequently, the fruit (ear). This result demonstrates that there was possibly a simultaneous effect of the water, osmotic, and nutritional stresses imposed on the crop along its growth, causing physiological alterations that lead to decrease in the production of good-quality ears (Nazário et al., 2013).

Figure 1B shows that a quadratic polynomial model fitted to the data of husked ear weight, with maximum of $60.83 \mathrm{~g}$, corresponding to water salinity of $2.52 \mathrm{dS} \mathrm{m}^{-1}$. For water salinity of $1 \mathrm{dS} \mathrm{m}^{-1}$, HEW was equal to $50.69 \mathrm{~g}$ and for water salinity of $5 \mathrm{dS} \mathrm{m}^{-1}$ it was equal to $33.87 \mathrm{~g}$, that is, there was a $33.18 \%$ reduction between the extreme values of salinity. Sousa et al. (2010) found that maize plants under salt stress allocated more sodium in the vegetative organs than in reproductive ones after 90 days of field experiment, probably as one of the strategies to mitigate the deleterious effects of salts on the plant and consequently on the fruit. This strategy may favor, up to a certain limit of salinity, the production of the better quality ear observed in the present study.

In peanut plants subjected to salt stress and different leaching fractions, Santos et al. (2012) found that the dry mass of the pod with grains decreased as the electrical conductivity of the saturation extract increased, due to the lower cell turgor, which leads to reduction in the number of leaves and plant growth.

Carvalho et al. (2012) found that husked ear weight was higher in plants irrigated with water of lower electrical
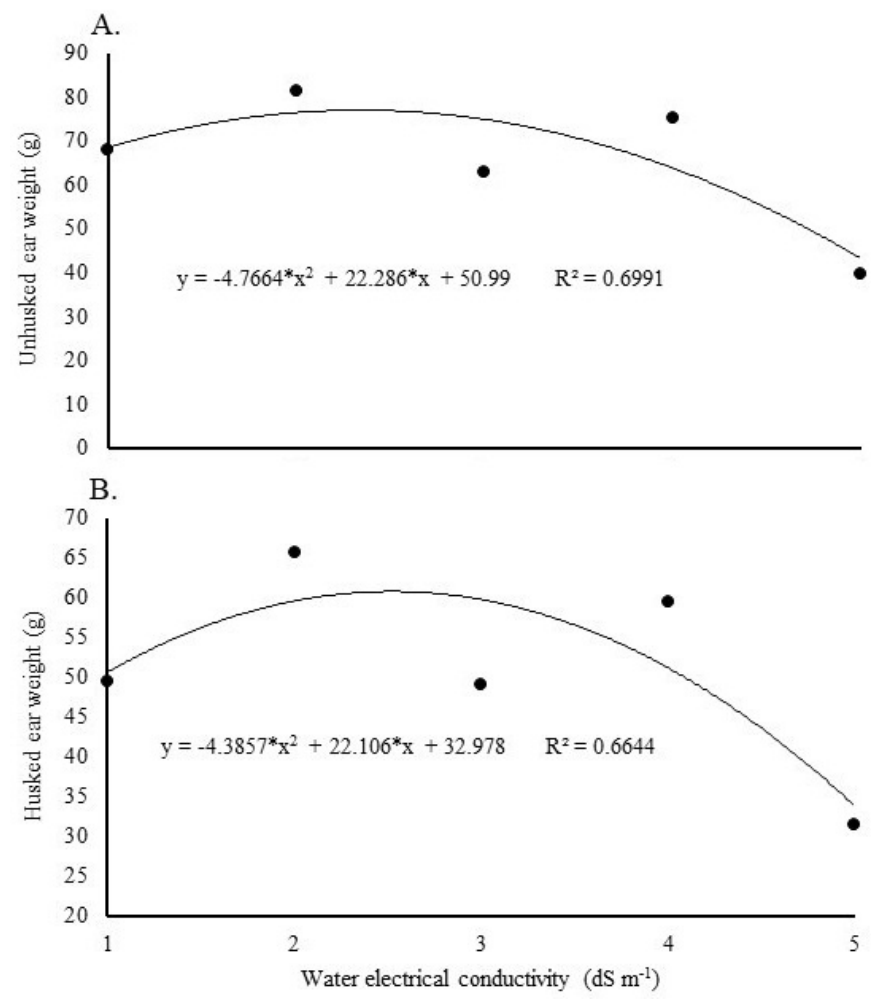

* Significant at $\mathrm{p} \leq 0.05$ by $\mathrm{F}$ test

Figure 1. Unhusked (A) and husked ear weight (B) of maize plants irrigated with saline waters at 110 days after planting

conductivity $\left(1.2 \mathrm{dS} \mathrm{m}^{-1}\right)$ compared to water of higher salinity level $\left(3.3 \mathrm{dS} \mathrm{m}^{-1}\right)$, due to the lower presence of salts in the soil, because it is known that the salts reduce the osmotic potential of the soil, making it difficult for plant roots to absorb water. These authors reported that the use of leaching depths contributed to the removal of salts in the soil profile, especially in the plots where water of lower salinity was applied.

As observed for UEW and HEW, cob weight was also affected $(\mathrm{p} \leq 0.01)$ by the increase in the salinity level of the irrigation waters. This variable showed a maximum value of $17.86 \mathrm{~g}$ at the water conductivity level of $2.13 \mathrm{dS} \mathrm{m}^{-1}$ (Figure 2) and decreased up to $9.62 \mathrm{~g}$ at water salinity of $5.0 \mathrm{dS} \mathrm{m}^{-1}$.

There were reductions of up to $52.5 \%$ in cob weight between the waters of lowest $\left(1.0 \mathrm{dS} \mathrm{m}^{-1}\right)$ and highest $\left(5.0 \mathrm{dS} \mathrm{m}^{-1}\right)$ salinity level. In other words, the ears probably underwent negative changes when water salinity increased to levels above the threshold salinity $\left(1.7 \mathrm{dS} \mathrm{m}^{-1}\right)$ according to Ayers \& Westcot (1999). Contradicting this study, Lacerda et al. (2011) did not find significant differences in this variable when plants were irrigated with water of up to $5.0 \mathrm{dS} \mathrm{m}^{-1}$, but observed

Table 2. Summary of the analysis of variance for unhusked ear weight (UEW), husked ear weight (HEW), cob weight (CW), husked ear diameter (ED), husked ear length (EL), 1000-grain weight (1000GW) and yield (Y) in maize plants irrigated with water of different salinity

\begin{tabular}{lcccccccc}
\hline \multirow{2}{*}{ SV } & DF & \multicolumn{7}{c}{ Mean square } \\
\cline { 3 - 9 } & & UEW & HEW & CW & ED & EL & $1000 \mathrm{GW}$ & Y \\
Blocks & 3 & $190.27^{\text {ns }}$ & $105.84^{\text {ns }}$ & $26.18^{\text {ns }}$ & $2.55^{\text {ns }}$ & $1.03^{\text {ns }}$ & $114.53^{\text {ns }}$ & $80419.79^{\text {ns }}$ \\
Treatment & 4 & $1025.18^{*}$ & $660^{*}$ & $1485.91^{* *}$ & $25.39^{\text {ns }}$ & $2.95^{\text {ns }}$ & $3123.78^{*}$ & $2122702.5^{* *}$ \\
Residual & 12 & 238.95 & 187.59 & 232.79 & 8.29 & 1.25 & 646.76 & 84551.75 \\
Total & 19 & & & & & & \\
Overall mean & & $65.41 \mathrm{~g}$ & $50.97 \mathrm{~g}$ & $75.53 \mathrm{~g}$ & $31.23 \mathrm{~cm}$ & $13.99 \mathrm{~cm}$ & $127 \mathrm{~g}$ & $2408.89 \mathrm{~kg} \mathrm{ha}^{-1}$ \\
CV (\%) & & 23.63 & 26.87 & 20.2 & 9.22 & 7.98 & 20.02 & 12.07 \\
\hline
\end{tabular}

SV - Source of variation; DF - Degrees of freedom; CV - Coefficient of variation; ${ }^{\text {ns }}$ - Not significant, ${ }^{* *}$ and ${ }^{*}$ - Significant at $\mathrm{p} \leq 0.01$ and $\mathrm{p} \leq 0.05$ by F test, respectively 


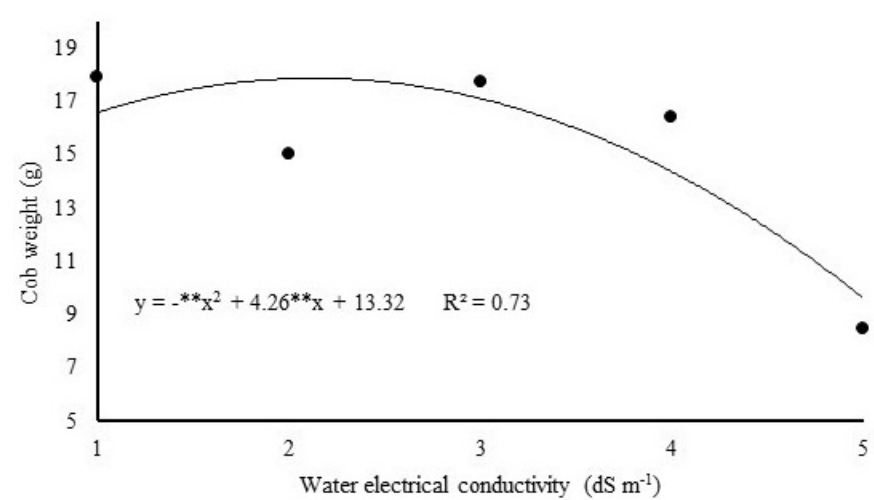

** Significant at $\mathrm{p} \leq 0.01$ by $\mathrm{F}$ test

Figure 2. Cob weight of maize plants irrigated with saline waters at 110 days after planting

reductions of yield when plants were irrigated with water from 0.8 to $5.0 \mathrm{dS} \mathrm{m}^{-1}$.

For the 1000-grain weight, the regression equation that best fitted was the quadratic polynomial model (Figure 3) and its maximum (145.94 g) was obtained in the irrigation water of $1.98 \mathrm{dS} \mathrm{m}^{-1}$, decreasing to $89.16 \mathrm{~g}$ after this point.

This demonstrates that the best grains were obtained at lower levels of salinity, due to the disturbances that toxic ions can cause in plant metabolism as salinity increases, leading to reduction in potassium absorption and consequently in grain quality (Munns \& Gilliham, 2015; Taiz et al., 2017).

In another study also with maize plants, conducted in the semiarid region of China, Yuan et al. (2018) described that the continuous use of water with salinity above the crop threshold $\left(1.7 \mathrm{dS} \mathrm{m}^{-1}\right)$ reduces the 1000 -grain weight.

Working with irrigation water of $12 \mathrm{dS} \mathrm{m}^{-1}$ in sorghum plants (Sorghum bicolor L.), Shakeri et al. (2017) reported that there were reductions of up to $42 \%$ in the 1000 -grain weight compared to plants irrigated with low-salinity water $\left(2.0 \mathrm{dS} \mathrm{m}^{-1}\right)$.

The electrical conductivity of irrigation water caused linear reductions in yield (Figure 4 ) of 13.45, 26.89, 40.34 and $53.78 \%$ for ECw of 2.0, 3.0, 4.0 and $5.0 \mathrm{dS} \mathrm{m}^{-1}$, respectively, in comparison to low-salinity water $\left(1.0 \mathrm{dS} \mathrm{m}^{-1}\right)$. Irrigation using water of $1.0 \mathrm{dS} \mathrm{m}^{-1}$ resulted in yield of $3295 \mathrm{~kg} \mathrm{ha}^{-1}$, while water of $5.0 \mathrm{dS} \mathrm{m} \mathrm{m}^{-1}$ led to yield of $1523 \mathrm{~kg} \mathrm{ha}^{-1}$. There was a $13.45 \%$ reduction per unit increase in water electrical conductivity, i.e., $443.1 \mathrm{~kg} \mathrm{ha}^{-1}$.

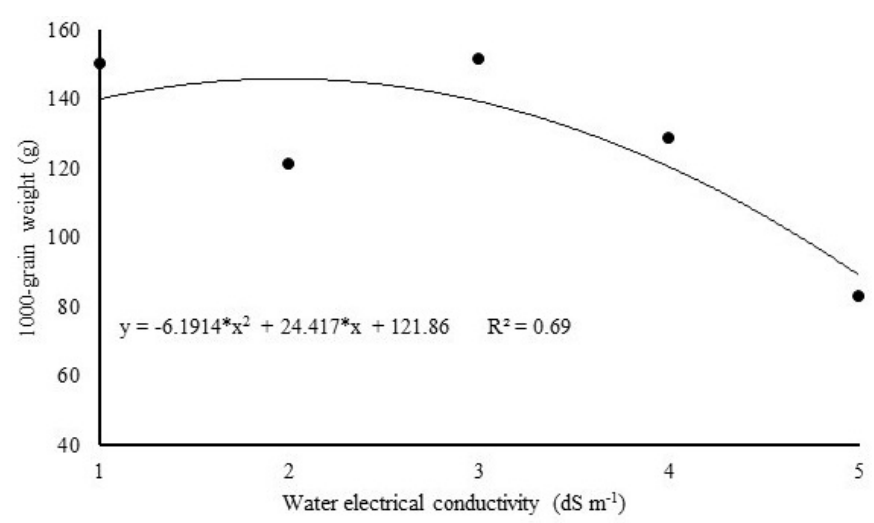

* Significant at $\mathrm{p} \leq 0.05$ by $\mathrm{F}$ test

Figure 3. 1000-grain weight of maize plants irrigated with saline waters at 110 days after planting

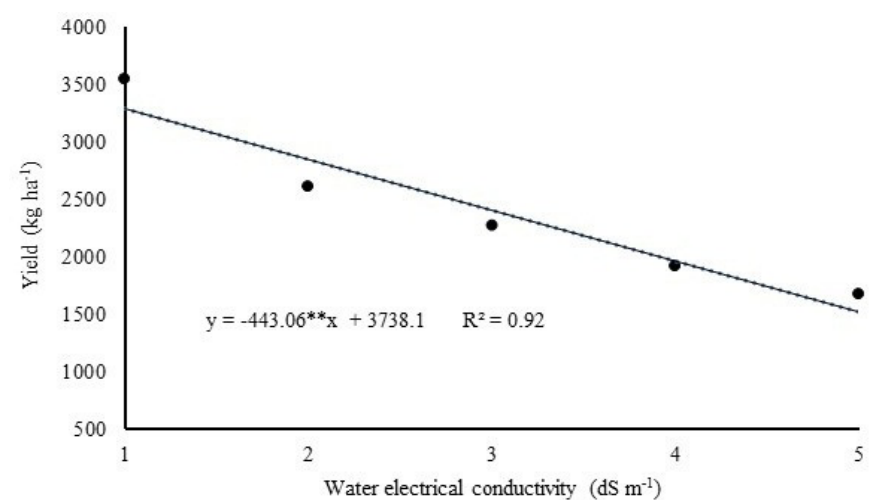

** Significant at $\mathrm{p} \leq 0.01$ by $\mathrm{F}$ test

Figure 4. Grain yield of maize plants irrigated with saline waters at 110 days after planting

The reduction in grain yield caused by the progressive salt stress is related to the deviation of energy due to the increased levels of soil salinity and to the metabolic cost of energy associated with an attempt to adapt to salinity (Garcia et al., 2007; Lima et al., 2018).

The negative effect of irrigation water salinity on yield was substantial, showing that the production is compromised by the presence of salts in the water. Similar results were found by Isla \& Aragués (2010), who observed that the threshold salinity was $2.8 \mathrm{dS} \mathrm{m}^{-1}$ in the second year of maize cultivation under saline water irrigation, and from this value the yield began to decrease. The same authors cited that there were reductions of yield of about $80 \%$ in the saline treatment $\left(4.5 \mathrm{dS} \mathrm{m}^{-1}\right)$, compared to the control treatment.

Barbosa et al. (2012), in a study with maize plants and cyclic use of saline water with good-quality water, observed yield reductions when plants were irrigated throughout the cycle using water with electrical conductivity of $4.5 \mathrm{dS} \mathrm{m}^{-1}$. At this salinity level, the authors obtained yield of $6067 \mathrm{~kg} \mathrm{ha}^{-1}$. Feng et al. (2017), also in maize plants cultivated without drainage, found yields of 7012 and $7328 \mathrm{~kg} \mathrm{ha}^{-1}$ under irrigation with low-salinity water $\left(0.78 \mathrm{dS} \mathrm{m}^{-1}\right)$ in the years 2014 and 2015, respectively; however, under irrigation with $6.25 \mathrm{dS} \mathrm{m}^{-1}$ water, the yield dropped to 5838 and $5532 \mathrm{~kg} \mathrm{ha}^{-1}$ in 2014 and 2015, respectively.

\section{Conclusions}

1. The increase of salt concentration in irrigation water causes significant reduction in the variables unhusked and husked ear weights, cob weight and yield of maize plants.

2. Increase in irrigation water salinity above $1.98 \mathrm{dS} \mathrm{m}^{-1}$ reduced the 1000-grain weight.

3. Ear diameter and length were not affected by the salinity levels used.

\section{ACKnowledgments}

The authors thank the Fundação Cearense de Apoio ao Desenvolvimento Científico e Tecnológico (FUNCAP) for funding the project and the Coordenação de Aperfeiçoamento de Pessoal de Nível Superior (CAPES) for granting the master's scholarship to the first author. 


\section{Literature Cited}

Alvares, C. A.; Stape, J. L.; Sentelhas, P. C.; Gonçalves, J. L. M.; Sparovek, G. Köppen's climate classification map for Brazil. Meteorologische Zeitschrift, v.22, p.711-728, 2013. https://doi. org/10.1127/0941-2948/2013/0507

Ayers, R. S.; Westcot, D. W. A qualidade da água na agricultura. Campina Grande: UFPB, 1999. 153p. Irrigação e Drenagem, 29

Ashraf, M.; Shahzad, S. M.; Akhtar, N.; Imtiaz, M.; Ali, A. Salinization/ sodification of soil and physiological dynamics of sunflower irrigated with saline-sodic water amending by potassium and farm yard manure. Journal of Water Reuse and Desalination, v.7, p.476-487, 2017. https://doi.org/10.2166/wrd.2016.053

Ashraf, M.; Shahzad, S. M.; Siddiqui, A. R.; Piracha, M. A. Management of brackish water for irrigating sunflower (Helianthus annuus L.) through integrated use of potassium and farm yard manure. In: International Training Workshop on Sustainable Agriculture Water Management in a Changing Environment: A Special Focus on Olive Tree, Rawalpindi, 2015. Proceedings... Rawalpindi: PMAS-Arid Agriculture University, 2015. p.111-117.

Barbosa, F. S.; Lacerda, C. F.; Gheyi, H. R.; Farias, G. C.; Silva Júnior, R. J. C.; Lage, Y. A.; Hernandez, F. F. F. Yield and ion content in maize irrigated with saline water in a continuous or alternating system. Ciência Rural, v.42, p.1731-1737, 2012. https://doi. org/10.1590/S0103-84782012001000003

Carvalho, J. F. de; Tsimpho, C. J.; Silva, Ê. F. de F. e; Medeiros, P. R. F. de; Santos, M. H. V. dos; Santos, A. N. dos. Produção e biometria do milho verde irrigado com água salina sob frações de lixiviação. Revista Brasileira de Engenharia Agrícola e Ambiental, v.16, p.368374, 2012. https://doi.org/10.1590/S1415-43662012000400006

Doorenbos, J.; Kassam, A. H. Efeito da água no rendimento das culturas. Campina Grande: UFPB, 1994. 306p. Irrigação e Drenagem, 33

EMBRAPA - Empresa Brasileira de Pesquisa Agropecuária. Manual de métodos de análises de solo. 2.ed. Rio de Janeiro: Ministério da Agricultura e do Abastecimento, 1997. 212p.

Feng, G.; Zhang, Z.; Wan, C.; Lu, P.; Bakour, A. Effects of saline water irrigation on soil salinity and yield of summer maize (Zea mays L.) in subsurface drainage system. Agricultural Water Management, v.193, p.205-213, 2017. https://doi.org/10.1016/j. agwat.2017.07.026

Garcia, G. de O.; Ferreira, P. A.; Miranda, G. V.; Oliveira, F. G. de; Santos, D. B. dos. Índices fisiológicos, crescimento e produção do milho irrigado com água salina. Irriga, v.12, p.307-325, 2007. https://doi.org/10.15809/irriga.2007v12n3p307-325

Holanda Filho, R. S. F. de; Santos, D. B. dos; Azevedo, C. A. V. de; Coelho, E. F.; Lima, V. L. A. de. Água salina nos atributos químicos do solo e no estado nutricional da mandioqueira. Revista Brasileira de Engenharia Agrícola e Ambiental, v.15, p.60-66, 2011. https://doi.org/10.1590/S1415-43662011000100009

Isla, R.; Aragüés, R. Yield and plant ion concentrations in maize (Zea mays L.) subject to diurnal and nocturnal saline sprinkler irrigations. Field Crops Research, v.116, p.175-183, 2010. https:// doi.org/10.1016/j.fcr.2009.12.008
Lacerda, C. F. de; Sousa, G. G. de; Silva, F. L. B.; Guimaraes, F. V. A.; Silva, G. L.; Cavalcante, L. F. Soil salinization and maize and cowpea yield in the crop rotation system using saline waters. Engenharia Agrícola, v.31, p.663-675, 2011. https://doi. org/10.1590/S0100-69162011000400005

Lima, G. S. de; Dias, A. S.; Gheyi, H. R.; Soares, L. A. dos A.; Andrade, E. M. G. Saline water irrigation and nitrogen fertilization on the cultivation of colored fiber cotton. Revista Caatinga, v.31, p.151160, 2018. https://doi.org/10.1590/1983-21252018v31n118rc

Munns, R.; Gilliham, M. Salinity tolerance of crops: What is the cost? New Phytologist, v.208, p.668-673, 2015. https://doi.org/10.1111/ nph.13519

Nazário, A. A.; Bestete, L. de O.; Garcia, G. de O.; Reis, E. F. dos; Cecílio, R. A. Desenvolvimento e produção do milho irrigado com água de diferentes condutividades elétricas. Engenharia Ambiental, v.10, p.117-130, 2013.

Rhoades, J. D.; Kandiah, A.; Mashali, A. M. Uso de águas salinas para produção agrícola. Campina Grande: UFPB, 2000. 117p. Irrigação e Drenagem, 48

Santos, D. B. dos; Ferreira, P. A.; Oliveira, F. G. de; Batista, R. O.; Costa, A. C.; Cano, M. A. O. Produção e parâmetros fisiológicos do amendoim em função do estresse salino. Idesia, v.30, p.69-74, 2012. https://doi.org/10.4067/S0718-34292012000200009

Santos, J. M. A. P. dos; Oliveira, F. A. de; Medeiros, J. F. de; Targino, A. J. O.; Costa, L. P. da; Santos, S. T. dos. Saline stress and potassium/ calcium ratio in fertigated eggplant. Revista Brasileira de Engenharia Agrícola e Ambiental, v.22, p.770-775, 2018. https:// doi.org/10.1590/1807-1929/agriambi.v22n11p770-775

Shakeri, E.; Emama, Y.; Tabatabaei, S. A.; Sepaskhah, A. R. Evaluation of grain sorghum (Sorghum bicolor L.) lines/cultivars under salinity stress using tolerance indices. International Journal of Plant Production, v.11, p.101-116, 2017.

Silva, F. de A. S. e; Azevedo, C. A. V. de. The Assistat Software Version 7.7 and its use in the analysis of experimental data. African Journal of Agricultural Research, v.11, p.3733-3740, 2016. https://doi. org/10.5897/AJAR2016.11522

Sousa, G. G. de; Lacerda, C. F. de; Cavalcante, L. F.; A Guimarães, F. V.; Bezerra, M. E. de J.; Silva, G. L. da. Nutrição mineral e extração de nutrientes de planta de milho irrigada com água salina. Revista Brasileira de Engenharia Agrícola e Ambiental, v.14, p.1143-1151, 2010. https://doi.org/10.1590/S1415-43662010001100003

Taiz, L.; Zeiger, E.; Møller, I.; Murphy, A. Fisiologia e desenvolvimento vegetal. 6.ed. Porto Alegre: Artmed, 2017. 888p.

Yuan, C. F.; Feng, S. Y.; Wang, J.; Huo, Z. L.; Ji, Q. Y. Effects of irrigation water salinity on soil salt content distribution, soil physical properties and water use efficiency of maize for seed production in arid Northwest China. International Journal of Agricultural and Biological Engineering, v.11, p.137-145, 2018. https://doi. org/10.25165/j.ijabe.20181103.3146

Yu, X.; Liao, Y.; Oladipo, I. O. Effect of salinity water irrigation on maize growth in northwest region. Journal of Chemical and Pharmaceutical Research, v.6, p.300-305, 2014. 